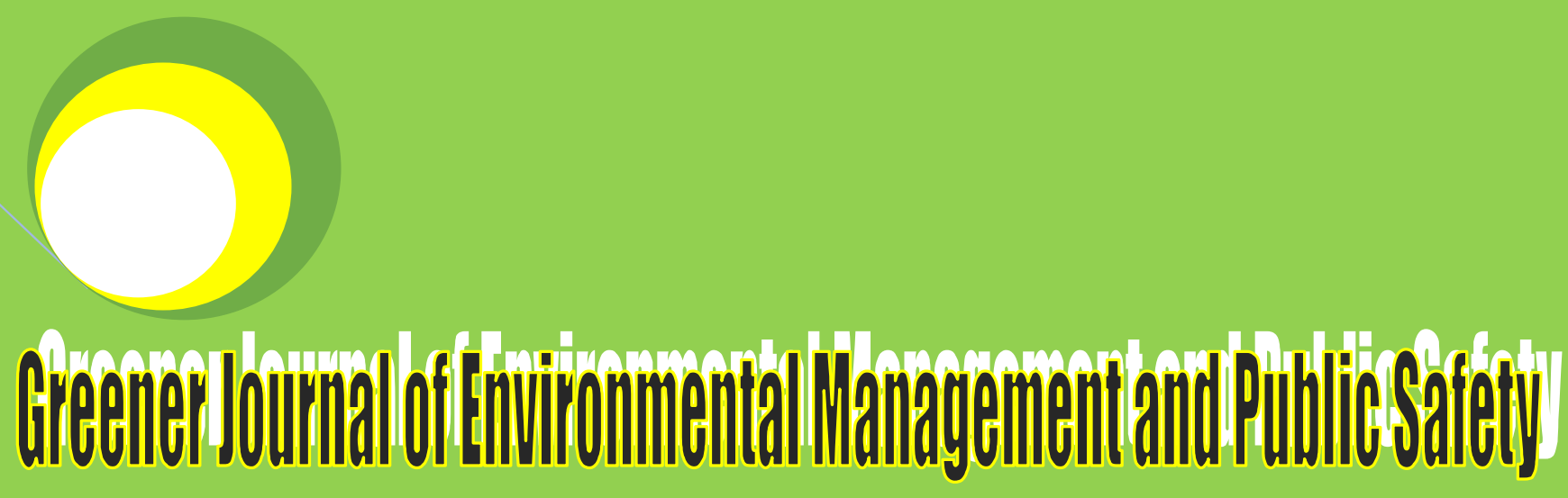

ISSN: 2354-2276

Submitted: $21 / 06 / 2017$

Accepted: 24/06/2017

Published: 29/06/2017

Review on the

Environmental

Impacts of Municipal

Solid Waste in

Nigeria: Challenges

and Prospects

By

Tariwari C. N. Angaye

Jasper F. N. Abowei 


\title{
Review on the Environmental Impacts of Municipal Solid Waste in Nigeria: Challenges and Prospects
}

\author{
*Tariwari C. N. Angaye and Jasper F. N. Abowei \\ Department of Biological Sciences, Niger Delta University, Wilberforce Island, Bayelsa State, Nigeria. \\ *Corresponding Author's E-mail: maktarry@ yahoo. Com; Mobile: +2347037889063.
}

\begin{abstract}
This review provides insight on the environmental impacts of municipal solid wastes (MSWs) in Nigeria. The anthropogenic impacts of waste streams that infringes on ambient air quality, both ground and surface water, soil as well as biodiversity in dumpsites are discussed. The precarious generation of large waste stream whose leachates and effluent contaminate the environment is largely due to lack of sensitization, poor legislation, population expansion, industrialization and inadequate funding of the sector by Government. Besides the adverse impacts on various forms of biodiversity, Poor management of waste have the ability to limit aesthetic values of vital resources in the ecosystem, thereby increasing the incidence of global warming. An Integrated approach has become necessary for the efficient, safe and effective management of MSW, including more efforts by; individual effort, Local, State and Federal government, and the role of other stakeholders, pressure groups in the private sector are paramount.
\end{abstract}

Keywords: MSW, Air quality, Water, Soil, Pollution, Leachate.

\subsection{INTRODUCTION}

The problems posed by improper and ineffective management of Municipal Solid wastes (MSWs) has become an issue of global concern over the past decades. The magnitude of waste stream has acquired some abrupt dimensions (Schwarz-Herion, 2008; Amuda et al., 2014), with corresponding ineffective and inadequate management strategies (Angaye et al., 2015a), including insufficient funding on the part of Government (Doan, 1998; Hossain et al., 2014). The incidence of poor waste handling that has infringed on vital environmental components; including but not limited to soil, water and to air quality. Also, the magnitude of commercialization, industrialization and population expansion of most cities all over the world has also had its attendant adverse effects on the environment (Abur et al., 2014).

In Nigeria, statistical data as reported in literature by Ayuba et al. (2013) showed that municipal waste density ranges from $280-370 \mathrm{~kg} / \mathrm{m}^{3}$, while the rate of daily waste generation is about $0.44-0.66 \mathrm{~kg} /$ capital $/$ day (Ogwueleka, 2009), with an annual generation of 25 million tons. Furthermore, as documented in literature, Nigerian urban population has witnessed a remarkable abrupt growth due to rural-urban migration (Adejobi and Olorunnimbe, 2012), largely necessitated by yearning of the populace to keep abreast or understand contemporary technological applications. Unfortunately, high population density is implicated in poor handling of large waste streams generated, due to inadequate waste facilities and consequently results to environmental pollution. In most developing countries, anthropogenic activities associated with the precarious disposal of MSWs poses more grave consequences to the ecosystem, besides being threat to public health (Adamu et al.2014).

The quality of very sensitive environmental media (air quality, soil and water), and keystone resource are largely infringed upon by MSWs. For instance, toxic or contaminable leachates from MSWs dumpsites could be transformed physically, chemically or biologically (Al Sabahi et al., 2009), and transported via the air, or through runoffs which can contaminate either the soil, surface or/and groundwater (Christensen et al., 1998; KolaOlusanya, 2012). Also, toxic fumes and greenhouse gases are also being produced by precarious or uncontrolled in-situ burning (Okeke, 2014), which could have acute or chronic health and environmental consequences (Jalil, 2010; Adekunle et al., 2011; Ayuba et al., 2013).

According to Onwughara et al. (2010), the management strategies of MSWs varies per country but not limited to landfill system, incineration and recycling. They also reported that; underdeveloped nations use landfill system, while developed nations like; the United States Japan and Australia use mostly use the recycling method. Although in Nigeria waste recycling has been encouraged by all stakeholders, but unfortunately it is yet to attain full recognition due to slow implementation and insufficient funding. As such the commonest method of disposal in Nigeria still remains open dump and landfill system and insitu incineration (Momodu et al.2011), which are very prone to environmental pollution. 


\subsection{MUNICIPAL SOLID WASTE}

Solid wastes are referred to as unwanted or needless non-liquid substances which can be referred to as garbage or refuse as opposed to liquid waste which are called effluent. The American Public Works Association defined solid waste as needless or ready to be discarded substances with inadequate liquid component. Municipal solid waste in this context refers to solid or non-gaseous wastes arising from domestic, industrial, commercial or agriculture origin (Adedibu, 1983). It was reported by Abur et al., (2014) that due to the poor management of municipal solid waste management in developing nation like Nigeria, conservation of the ecosystem and other vital resources has become a major challenge. While waste characterization is very key in efficient and successful management of municipal waste (Guadalupe et al, 2009); It is noteworthy that most cities across Nigeria municipal solid waste are usually to characterised prior to their disposal, leaving their toxic and untreated components to undergo transformation thereby infringe on fragile system of the environment.

\subsection{Categories of Municipal Solid Wastes}

Municipal Solid waste (MSW), are referred to as ready to discarded or needless non-liquid substances or material originating from human activities, including domestic and industrial sources. Human activities create vast streams of wastes and pollutants, which are capable of infringing on vital components of the ecosystem (reference). Municipal solid waste (MSW), commonly known as trash or garbage in the United States and as refuse or rubbish in Britain, is a waste type consisting of everyday items that are discarded by the public. "Garbage" can also refer specifically to food waste, as in a garbage disposal; the two are sometimes collected separately. There are basically two sources of MSWs, which are domestic and commercial sources (Momodu et al.2011). Domestic Sources, refers to general household wastes which includes food waste, rubbish, ashes and special wastes. While commercial sources are referring to waste originating from commercial activities like restaurants, shops, auto-mechanic repairs, medical facilities, schools, construction activities and other special wastes (references). Furthermore, wastes may be classified according their source, properties, degradability, toxicity. Classification based on point source is presented in Table 1 below:

Table 1: Classification of Solid Waste based on Source

\begin{tabular}{|l|l|l|l|l|}
\hline S/N & $\begin{array}{l}\text { Classes of } \\
\text { Waste }\end{array}$ & $\begin{array}{l}\text { Characteristics and } \\
\text { Possible Source }\end{array}$ & \multicolumn{1}{|c|}{ Typical Examples } & References \\
\hline 1. & $\begin{array}{l}\text { Household } \\
\text { Solid waste }\end{array}$ & $\begin{array}{l}\text { Specific solid wastes } \\
\text { originating from } \\
\text { Domestic activities }\end{array}$ & $\begin{array}{l}\text { Food items, clothes, damage utensils, } \\
\text { ashes, garden waste }\end{array}$ & $\begin{array}{l}\text { NEST 1991; 1995; } \\
\text { Anyakoha and } \\
\text { Egboeli; 1993 }\end{array}$ \\
\hline 2. & $\begin{array}{l}\text { Organic } \\
\text { Waste }\end{array}$ & $\begin{array}{l}\text { Solid biodegradable } \\
\text { waste }\end{array}$ & $\begin{array}{l}\text { Leaves, vegetables, fruits, food scraps, } \\
\text { carcass, wood etc. }\end{array}$ & $\begin{array}{l}\text { NEST, 1991; } \\
\text { Adamu et al.2014 }\end{array}$ \\
\hline 3. & $\begin{array}{l}\text { Plastic } \\
\text { waste }\end{array}$ & $\begin{array}{l}\text { Usually } \\
\text { degradable or non- } \\
\text { degradable } \text { nomi- }\end{array}$ & $\begin{array}{l}\text { polythene bags, package water bags, } \\
\text { plastic products, used tyres, old electrical } \\
\text { appliances, phone casing etc. }\end{array}$ & $\begin{array}{l}\text { NEST, 1991; Botkin } \\
\text { and Keller, 1997 }\end{array}$ \\
\hline 4. & Metal waste & $\begin{array}{l}\text { Metallic waste } \\
\text { recalcitrant, could be } \\
\text { toxic due to their } \\
\text { leachability to the } \\
\text { environment }\end{array}$ & $\begin{array}{l}\text { buckets, spoons, plates, pots, pans, } \\
\text { sinks, poles, scrap cars, refrigerators, } \\
\text { generators, air conditioners, empty tins } \\
\text { etc. }\end{array}$ & $\begin{array}{l}\text { NEST, } \\
\text { Adamu et al.2014 }\end{array}$ \\
\hline 5. & Glass & $\begin{array}{l}\text { These are made up of } \\
\text { broken or discarded } \\
\text { glassware }\end{array}$ & $\begin{array}{l}\text { Drug, wine and chemical bottles } \\
\text { container, broken windscreen, ceramic } \\
\text { plates and cups, empty bottles of drugs, } \\
\text { chemicals, drinks }\end{array}$ & $\begin{array}{l}\text { Botkin and Keller, } \\
1997 ; \text { NEST 1991 }\end{array}$ \\
\hline
\end{tabular}

\subsection{Process of Municipal Solid Waste Management in Nigeria}

The process of municipal waste management involves several compounding and multifaceted procedures, which includes but not limited to; segregation, packaging/storage, collection, transportation, processing, resource recovering, recycling and disposal (Abila and Kantola, 2013; Oyekan and Sulyman 2013). Notwithstanding, the commonest method of waste disposal, the commonest are landfill system, incineration, composting and anaerobic digestion and recycling (Igbinomwanhia, 2011). Unfortunate, in most developing nations adherence to this procedure are not wholesomely adhered to, as wastes are usually dumped precariously in the bush or along the road. A study in 2003 by the health and Demography department of Nigerian National Population Commission indicated that only $14 \%$ of Nigerian have access to reliable household waste disposal system. It was also documented in literature that about $87 \%$ of Nigerian allegedly used unsanitary disposal system (Oyekan and Sulyman, 2015). These wastes could be transported by runoff during precipitation into pits and drainage 
(Babayemi and Dauda 2009; Onwughara et al.2010), or even infiltrates through the soil which they constitute major environmental problems like groundwater pollution (Kola-Olusanya, 2012). The volume of waste generated is largely attributed to several compounding factors which includes; population density, income, industrialization, attitude and legislation of the catchment area (Adedibu, 1985). For instance, Abila and Kantola, (2013), reported that the quantities of MSW generated in rural communities are usually less and better managed compared to urban communities, for instance household waste are usually incinerated or used to feed domestic animals.

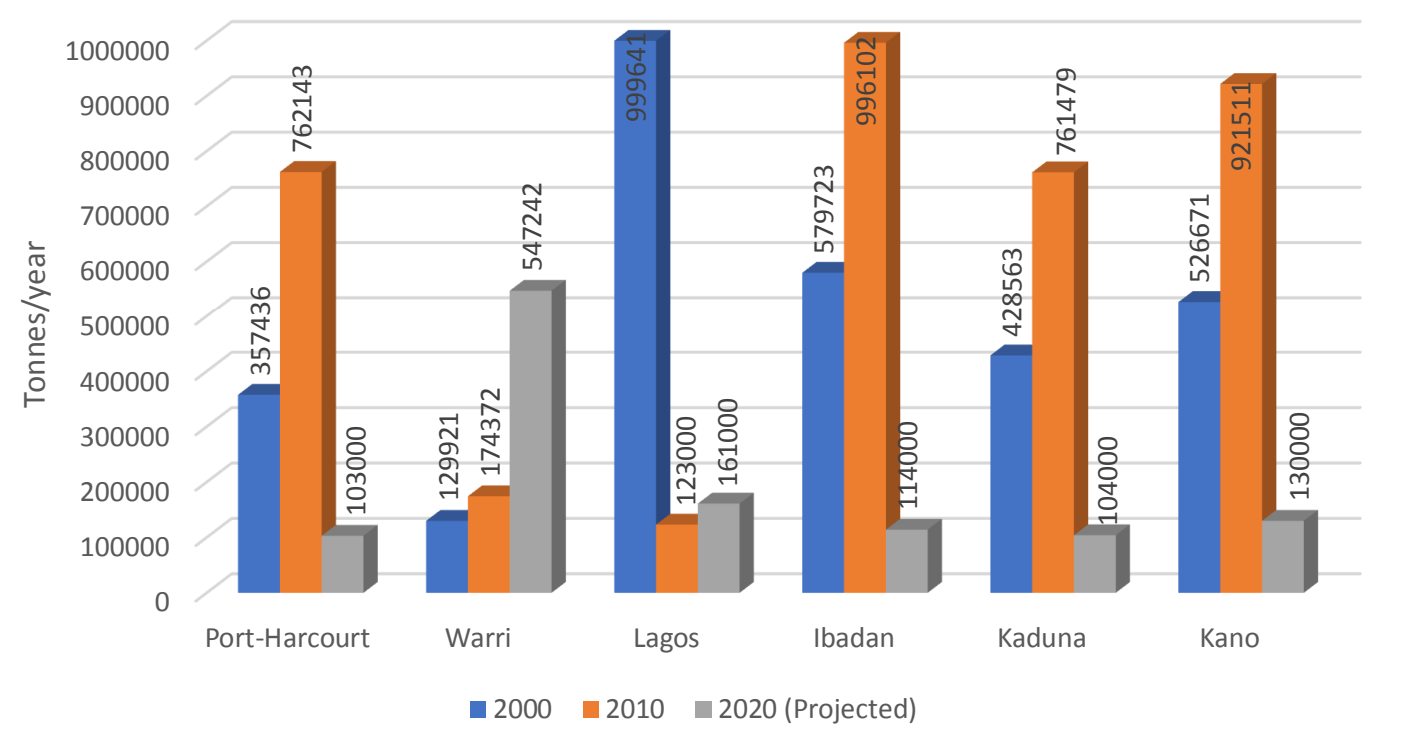

Figure 1: Estimated volumes of Municipal solid waste generated in some Nigerian cities

Besides the fact that there are lesser technological and industrial activities in rural settings, waste generated in rural communities are often degradable or bye products of agricultural origin. Unfortunately, due to maintenance cost, inadequate sensitization on danger posed and poor legislation, the commonest method of waste disposal and management in Nigeria has become, open dumping, landfill. The application of landfill system could envisage some environmental impacts which could be mitigated by adherence to aseptic and precautionary measures (Abila and Kantola, 2013), For instance, it was established in literature by Burney et al.(2011), that 49\% of England's methane emissions in 2007 were largely attributed to landfills system of waste disposal. Efficient and effective waste management in Nigeria should be implemented without much ado, this is broadly dependent on the three Rs policy (Reduce, Re-use, Recycle). In Nigeria, there is no formal recycling sector as solid waste, which majorly includes scrap metals and plastic are usually selectively recycled by scavengers based on their economic value.

Table 2: Percentage composition of Municipal Solid Waste in Some Major City Across Nigeria

\begin{tabular}{|c|c|c|c|c|c|c|c|}
\hline State & $\begin{array}{c}\text { Garbage/Food } \\
(\%)\end{array}$ & $\begin{array}{c}\text { Nylon/Plastic } \\
(\%)\end{array}$ & $\begin{array}{l}\text { Paper } \\
(\%)\end{array}$ & $\begin{array}{c}\text { Metal } \\
(\%)\end{array}$ & $\begin{array}{c}\text { Glass/Ceramic } \\
(\%)\end{array}$ & $\begin{array}{l}\text { Others } \\
(\%)\end{array}$ & Reference \\
\hline Abuja (FCT) & 53.80 & 7.04 & 9.58 & 2.54 & 7.32 & 20.28 & Abur et al., (2014) \\
\hline Akwa Ibom & 49.60 & 7.72 & 3.13 & 6.07 & - & 5.33 & Okey et al., (2013) \\
\hline Ilorin & 11.15 & 15.80 & 8.81 & - & - & 64.23 & Ahmed (2012) \\
\hline $\begin{array}{l}\text { Kano } \\
\text { Metropolis }\end{array}$ & 41.50 & 21.50 & 23.00 & 14.00 & - & - & Nabegu, $(2010 ; 2014)$ \\
\hline Edo State & 46.53 & 26.32 & 14.77 & 3.32 & 8.16 & 0.93 & Igbinomwanhia, (2012) \\
\hline Jigawa State & 60.58 & 5.95 & 7.01 & 12.17 & 14.29 & 8.06 & Musa et al., (2016) \\
\hline Enugu State & 46.16 & 35.32 & 10.17 & 6.84 & 2.57 & 11.92 & $\begin{array}{l}\text { Ugwuishiwu, et al., } \\
\text { (2016) }\end{array}$ \\
\hline $\begin{array}{ll}\text { Akwa } & \text { lbom } \\
\text { State } & \end{array}$ & 63.88 & 11.32 & 4.58 & 4.58 & 3.50 & 29.00 & Okey et al., (2013) \\
\hline $\begin{array}{l}\text { Abuja } \\
\text { Municipality }\end{array}$ & 54.96 & 20.22 & 12.84 & 5.84 & 4.38 & 1.63 & Ayuba et al., (2013) \\
\hline Kwara State & 11.21 & 15.79 & 8.80 & - & - & 64.19 & Ahmed, (2012) \\
\hline \multirow{4}{*}{$\begin{array}{l}\text { Nasarawa } \\
\text { State }\end{array}$} & 27.00 & 8.00 & 2.00 & 6.00 & 10.00 & 47.00 & \multirow{4}{*}{$\begin{array}{c}\text { Anyawu and Adefila, } \\
(2014)\end{array}$} \\
\hline & 34.00 & 8.00 & 4.00 & 8.00 & 10.00 & 36.00 & \\
\hline & 32.00 & 8.00 & 4.00 & 6.00 & 7.00 & 43.00 & \\
\hline & 33.00 & 4.00 & 4.00 & 6.00 & 12.00 & 59.00 & \\
\hline
\end{tabular}




\subsection{Sources and Fate of Municipal Solid Wastes}

Environmental pollution caused by municipal solid waste is mostly caused by human anthropogenic activities including quest to adopt contemporary technologies, urbanization, industrialization, with a corresponding inefficient waste management strategies (Rajaganapathy, et al.2011). Sources of contamination include: spills during transportation, poor containment of waste, surface runoff, uncontrolled insitu burning, inability to segregate waste, impromptu disposal of waste, siting of dumpsites close to water way and residential area etc. (Worksafe, 2005; Shayley et al.2009; Stavrianou, 2007). In addition, some of the populace lack technical know-how and personal orientation on the envisaged danger of precarious dumping of waste. It was documented in literature that the toxicity and fate of pollutants released from human activities is largely dependent on the source and target (Shayley et al.2009), as well as its leachability to the environment. Notwithstanding, there are several routes of exposures which includes inhalation, oral ingestion, eye or dermal contamination or through other human body orifices.

Furthermore, the adverse effects of any pollutant are largely dependent on its toxic properties, including the exposure rate and concentration of the toxicant (Stavrianou, 2007). Leachates from dumpsites can be transported by runoffs to contaminate either soil or other sources of water, thereby posing danger to species which depends on such water resources. Fate of contaminants can be intensified by certain compounding or synergistic factors including soil porosity, permeability, mineralogy, $\mathrm{pH}$, organic matter, moisture, temperature etc (Shayley et al.2009). It is also worthy of note that bioavailability also play vital role in the fate of some contaminants, for instance certain biodegraders might by synergistic with toxic waste or on the other hand mitigate their toxicity. For instance, in aquatic ecosystems, recalcitrant waste toxicant like heavy metal are usually soluble or suspended in water and their persistence will make them settle to the basal zone where they are bonded with sediment, and other forms abyssal biota (Aderinola et al.2009; Ene et al.2009; Obodai et al.2011).

\subsection{ENVIRONMENTAL IMPACTS OF MUNICIPAL SOLID WASTE IN NIGERIA}

\subsection{Some Environmental Aspects of Solid Waste in Nigeria}

\subsubsection{Environmental Degradation}

Environmental degradation is inevitable, when there is unsafe and precarious dumping of untreated MSWs on fragile components of ecosystem, as well as the corresponding attendant effects physicochemical and natural agents that transform waste. Furthermore, the persistent accumulation of toxic and recalcitrant wastes on land pollutes the environment and further limits its application (Singh, 1998; Akinjare, 2011). In addition, MSW could limit the aesthetic values of key resource in the environment. For instance, MSWs have the ability to plug drainage channels which can lead to excessive flooding during precipitation (Oyekan and Sulyman, 2015). Also, solid waste dumping is an eyesore which limits the accessibility, and alters the comfort, habitability and attractiveness from its normal state (Oyediran, 1995). Also, the incidence of ground water pollution as a result of poor waste landfill system that results arising from leachate percolation cannot be overemphasized (Mor et al.2006). Recent literature also revealed that vegetation found in dumpsites have the ability to bioaccumulate anthropogenic agent. To a great extent unregulated dumping also limit soil productivity for agrarian purpose (Anikwe and Nwobodo, 20002)

\subsubsection{Environmental Pollution}

Solid degradable waste in synergy with environmental factors and bio-degraders or both comes with environmental impacts that limit the quality of air, soil, as well as both surface and ground water. For instance, under anaerobic condition methanogens (bacteria) can aid the release of methane gas (Amuda et al.2014), as well as $\mathrm{CO}_{2}$ or both (Nayono 2010; Lam and Lee, 2011; Ohimain and Izah, 2017), which degrade air quality and also aid the incidence of global warming. Besides this, other anthropogenic pollutants associated with MSWs pollutants including greenhouse gases such as: carbon dioxide, methane, oxides of sulphide, nitrogen; as well as heavy metals which includes but not limited to; Cadmium (Cd), Copper (Cu), Iron (Fe), Lead (Pb), Zinc (Zn), Aluminium (Al) are transported as leachate through the soil to underground water, or as runoff from one ecosystem to the other during precipitation which they could be biomagnified along the food chain by aquatic and terrestrial biota thereby resulting to pollution that induce adverse effect (Walker and Colwell, 1974). In a developing country like Nigeria, high MSW stream are generated with corresponding inadequate management strategies (Angaye et al.2015), largely due to financial constrains (van Beukering et al.1999; Omaran and Gavrilescu, 2008; Onwughara et al.2014) or weak legislation (Nkwachukwu et al.2010), thus resulting to the practice of open air insitu burning which have attendant greenhouse effect that results to global warming (Ayuba et al.2013; Amuda et al.2014). 


\subsubsection{Health consequences}

Illicit open of dumping of MSWs comes with grave health consequences due to the fact that dumpsites provide substrate for breeding, feeding and habitation of pathogenic organisms and vectors of public health importance. Oyekan and Sulyman (2015), reported that insects and vectors that transmits major diseases of public health are usually found in dumpsites. These vectors include but not limited to flies, mosquitos and rodents (Onibiokan, 2000). For instance, the breeding of flies is decomposing of organic waste, while mosquitoes are encouraged by piles of refuse like, car tyres, empty cans etc., these vectors play vital roles in the transmission of disease of public health importance like plague, amoebic dysentery, rat bite fever, Lassa fever etc (Barina, 2003; Adamu et al.2014). Vegetation grown in contaminated soil have the ability to bioaccumulate toxic heavy metals, in their tissues which pose potential health risks as they could biomagnify in the consumer's tissue (Onwughara et al.2014).

\subsection{Impact of MSW on Air Quality}

As presented in Table 3 below, literature survey of air quality around Nigerian MSW dumpsites showed that values exceed threshold limits of the Federal Environmental Protection Agency. These is largely attributed to unsafe management of MSW including uncontrolled open air insitu burning of waste, whose direct effects on biodiversity and greenhouse effect cannot be overemphasized. Statistical data based on mortalities attributed to air pollution and the synergistic role they play in the development of respiratory diseases (Barakat-Haddad, 2015), the World Health Organisation has recently identified air pollution as a basic health hazard (WHO, 2014). The generation and poor management of MSWs in Nigeria comes with adverse attendant environmental and health effect. Air Pollution associated with solid dumpsites has become a major source of concern due foul odour released and the emission of greenhouse gases like: carbon monoxide, oxides of Nitrogen and Sulphur as well as release of suspended particulate matter during insitu burning (Lingan, et al.2014).

Furthermore, it was reported in literature that inadequacies in efficient waste management of most developing nations had impair human health and biodiversity with corresponding adverse effects on keystone resources (Sharholy et al.2008). For air quality pollution, the major route of exposure is by the process of inhalation (Barman, et al, 2010). Notwithstanding, air pollution can cause nasal, eyes and airway irritation, wheezing, coughing, anoxia, and even lung and heart problems, which increase risk to asthma and heart attack. Whereas in extreme cases it can result to mortality, the chronic exposure to air pollution can compromise the immune system and cause systemic cancer of the nervous, reproductive, and respiratory systems. Presented in Table 3 below are data of air quality around some MSW dumpsites in Nigeria.

Besides toxic emission during burning of waste, suspended particulates matter release contain anthropogenic substance which can carcinogenic, irritate the nasal cavity or the lungs and cause infections ranging from cold to other air-borne diseases (Bency et al.2003; Lingan et al.2014). Another report indicated that people whose abode are close to dumpsite are predispose to cardiovascular diseases (Nautiyal et al.2007; Barakat-Haddad, 2015), like bronchitis, lung cancer, cardiovascular disease, birth defect, asthma, and premature mortalities (Agwu and Ozeh, 2013). Another study on the relative aerobic microbial distribution of a dumpsite in Nigeria showed, 37\% Escherichia coli, 19\% Klebsiella spp, 13\% Pseudomonas spp, 15\% Serratia spp, $8 \%$ of Staphylococcus spp, $7 \%$ of Enterococcus spp, with the least being 1\% of Salmonella spp. (Odeyemi, 2012). 
Table 3: Air Quality Assessment around Some MSW Dumpsite in Nigeria

\begin{tabular}{|c|c|c|c|c|c|c|c|c|c|c|c|}
\hline State & Temp & $\mathbf{R H}$ & $\mathrm{H}_{2} \mathrm{~S}$ (ppm) & $\begin{array}{c}\text { SPM } \\
\text { (ppm) }\end{array}$ & CO (ppm) & $\begin{array}{c}\text { SOx } \\
\text { (ppm) }\end{array}$ & $\begin{array}{c}\text { NOx } \\
\text { (ppm) }\end{array}$ & $\begin{array}{c}\mathrm{NH}_{3} \\
\text { (ppm) }\end{array}$ & $\begin{array}{c}\mathrm{CH}_{4} \\
\text { (ppm) }\end{array}$ & $\begin{array}{l}\text { VOC } \\
\text { (ppm) }\end{array}$ & Reference \\
\hline & $30^{\circ} \mathrm{C}$ & NA & NS & $250 \mu \mathrm{g} / \mathrm{m}^{3}$ & $\begin{array}{l}10.0-20.0 \\
\text { ppm }\end{array}$ & $\begin{array}{l}0.01-0.10 \\
\text { ppm }\end{array}$ & $\begin{array}{l}0.04-0.06 \\
\text { ppm }\end{array}$ & NS & NS & NS & FEPA, (2001) \\
\hline $\begin{array}{l}\text { Imo State } \\
\text { (Morning) }\end{array}$ & - & - & $0.80-0.84$ & $\begin{array}{c}6.30- \\
6.80 \\
\end{array}$ & $0.28-0.31$ & $0.09-0.13$ & $0.08-0.11$ & $0.06-0.10$ & $0.12-0.14$ & - & \multirow[t]{2}{*}{$\begin{array}{l}\text { Ubouh et al. } \\
\quad(2016)\end{array}$} \\
\hline $\begin{array}{l}\text { Imo State } \\
\text { (Evening) }\end{array}$ & - & - & $0.79-0.82$ & 6.57 & $0.20-0.24$ & 0.11 & $0.07-0.10$ & $0.05-0.09$ & $0.09-0.12$ & - & \\
\hline Rivers State & $28.0-30.8$ & $\begin{array}{l}62.6- \\
68.40 \\
\end{array}$ & 0.06 & - & - & 0.230 & 0.037 & 0.000 & 0.06 & - & Weli et al.(2014) \\
\hline Abia State & - & - & - & - & - & - & $0.02-0.09$ & - & - & - & $\begin{array}{c}\text { Nwakanma et } \\
\text { al.(2016) }\end{array}$ \\
\hline $\begin{array}{ll}\text { Niger } & \text { Delta } \\
\text { States } & \\
\end{array}$ & - & - & $3.40-7.70$ & $773-801$ & $\begin{array}{l}133.7- \\
141.6\end{array}$ & $27.7-37.1$ & $21.0-27.3$ & $14.7-19.5$ & $\begin{array}{l}2310- \\
2771\end{array}$ & - & $\begin{array}{l}\text { Rim-Rukeh, } \\
\text { (2014) }\end{array}$ \\
\hline Ebonyi State & - & - & $0.03-0.07$ & - & $1.74-1.90$ & - & $0.05-0.12$ & $\begin{array}{l}0.047- \\
0.070\end{array}$ & - & - & $\begin{array}{l}\text { Njoku et } \\
\text { al.(2014) }\end{array}$ \\
\hline Rivers State & - & - & - & - & $0.00-4.00$ & $<0.01$ & $4.40-6.50$ & $1.00-1.20$ & - & $\begin{array}{c}0.40- \\
1.30\end{array}$ & $\begin{array}{l}\text { Ezekwe et } \\
\text { al.(2016) }\end{array}$ \\
\hline $\begin{array}{ll}\text { Kaduna } & \text { (Dry } \\
\text { Season) } & \\
\end{array}$ & - & - & $\begin{array}{l}0.00135- \\
0.0315\end{array}$ & - & $\begin{array}{l}1.500- \\
11.40\end{array}$ & $\begin{array}{c}0.0005- \\
0.0032\end{array}$ & 0.00605 & - & - & - & \multirow[t]{2}{*}{ Uba (2015) } \\
\hline $\begin{array}{ll}\text { Kaduna } & \text { (Wet } \\
\text { Season) } & \end{array}$ & - & - & $\begin{array}{l}0.0005- \\
0.0037\end{array}$ & - & $\begin{array}{l}1.50- \\
10.50\end{array}$ & $\begin{array}{l}0.0011- \\
0.0390\end{array}$ & $\begin{array}{l}0.00185- \\
0.00365\end{array}$ & - & - & - & \\
\hline
\end{tabular}


The environmental impacts of MSW on water and soil quality cannot be overemphasized, although soil texture and structure determines the degree of percolation. Ogedengbe and Akinbile (2007) reported that high degree of turbidity in ground water samples from dumpsites is due to the percolation of leachate. In the review results as reported by several authors indicates that most ground water located in dumpsites are contaminated, with values exceeding regulatory limits. In the same vein, higher level of heavy metals which contaminates groundwater have also been reported (Akpan, 2004; Bahnasawy et al.2011). Due to the solubility of these contaminants (Udoessien, 2004), the become persistent and accumulates to cause various adverse effects. As reported by Iwuoha et al. (2013), in surface water and sediment organic matters play vital regulatory role in determining heavy metal distribution. This is because they bind with heavy metals by the process of adsorption to form solution. Notwithstanding, the availability is dependent on some physicochemical factors including; temperature, $\mathrm{pH}$, hardness, exposure rate etc (IPCS, 2003; WHO, 2003). Some microbes of medical importance such as $E$. faecalis and $E$. coli have been isolated from ground water close to dumpsites in Nigeria, these strains of pathogen were reported to be resistant to some first line antibiotics (David and Oluyege, 2014).

As presented in Tables 4 and 5 below result of some physicochemical and heavy parameters as reported by the authors showed that both surface and ground water quality as well as soil around MSW dumpsites exceeds regulatory limits as stipulated by Nigerian Standard for Drinking Water Quality. These has been largely attributed to leachate percolation and transportation through surface runoff during precipitation (Angaye et al.2015; 2016; Adebara et. al., 2016). Varying concentrations of some have metals have been found in both soil and water samples collected from dumpsites including; Zinc, Lead, Manganese, Chromium, Copper, Cobalt, Mercury (Akinbile and Yusoff 2011; David and Oluyege, 2014; Adebara et. al., 2016). Due to the fact that heavy metals are usually persistent and recalcitrant to degradation, they remain in the soil or water body where they are bioaccumulated and moves from one trophic level to the other. For instance, Izah and Angaye (2016) reported that fishes have the ability to bioaccumulates heavy metals origination from waste stream. In terrestrial ecosystem plants were also reported to bioaccumulate heavy metals from soil in waste dumpsites, these heavy metal pollutants were reported to have limit the growth rate of phytodiversities (Eshalomi-Mario1 and Tanee, 2015), Also vital mineral content like chlorophyll and ascorbic acid content of phytodiversity of MSW have been limited due pollution (Falusi et al. 2016). 
Table 4: Physicochemical Quality of Groundwater Around Some MSW Dumpsite in Nigeria

\begin{tabular}{|c|c|c|c|c|c|c|c|c|c|c|c|c|}
\hline State & Source & $\begin{array}{l}\text { Temp. } \\
\left({ }^{\circ} \mathrm{C}\right)\end{array}$ & $\mathrm{pH}$ & $\begin{array}{c}\text { Cond } \\
(\mu \mathrm{s} / \mathrm{cm})\end{array}$ & $\begin{array}{c}\mathrm{DO} \\
(\mathrm{mg} / \mathrm{l})\end{array}$ & $\begin{array}{c}\text { Turbidity } \\
\text { (mg/l) }\end{array}$ & $\begin{array}{c}\text { TSS } \\
(\mathrm{mg} / \mathrm{l})\end{array}$ & $\begin{array}{c}\text { TDS } \\
(\mathrm{mg} / \mathrm{l})\end{array}$ & $\begin{array}{l}\text { Hardness } \\
(\mathrm{mg} / \mathrm{l})\end{array}$ & $\begin{array}{c}\text { Sulphate } \\
(\mathrm{mg} / \mathrm{l})\end{array}$ & $\begin{array}{l}\text { Nitrate } \\
\text { (mg/l) }\end{array}$ & Reference \\
\hline $\begin{array}{l}\text { NSDWQ } \\
\text { Limits }\end{array}$ & NA & Ambient & $6.50-8.50$ & - & - & 5.00 & - & 500 & 200 & - & 50 & NSDWQ (2007) \\
\hline $\begin{array}{l}\text { Cross } \\
\text { River }\end{array}$ & GW & $\begin{array}{l}26.45- \\
27.28 \\
\end{array}$ & $5.50-6.61$ & $\begin{array}{c}169- \\
564.95 \\
\end{array}$ & $\begin{array}{l}5.01- \\
11.68 \\
\end{array}$ & - & $\begin{array}{l}0.02- \\
0.62 \\
\end{array}$ & $\begin{array}{l}47.32- \\
211.70\end{array}$ & - & - & - & Udofia et al.(2016) \\
\hline $\begin{array}{l}\text { Osun } \\
\text { State }\end{array}$ & GW & $\begin{array}{c}27.4- \\
31.5\end{array}$ & $7.5-10.8$ & $70-364$ & - & - & - & $\begin{array}{c}49- \\
248.2\end{array}$ & - & - & - & Oyelanmi et al.(2013) \\
\hline Ekiti State & GW & - & $5.86-7.84$ & $\begin{array}{l}12.2- \\
23.4\end{array}$ & - & $1.0-8.0$ & $\begin{array}{c}181.6- \\
272.2\end{array}$ & - & $\begin{array}{l}324.6- \\
456.3\end{array}$ & $\begin{array}{l}235.0- \\
522.0\end{array}$ & $13.0-38.0$ & $\begin{array}{c}\text { David and Oluyege, } \\
(2014)\end{array}$ \\
\hline \multirow[t]{2}{*}{$\begin{array}{l}\text { Niger } \\
\text { State }\end{array}$} & Wet & - & $7.24-8.41$ & $\begin{array}{c}344-1- \\
91\end{array}$ & $\begin{array}{l}3.66- \\
8.78\end{array}$ & $\begin{array}{l}4.48- \\
37.70\end{array}$ & - & $\begin{array}{l}230.98- \\
730.97\end{array}$ & - & - & - & \multirow[t]{2}{*}{ Sadiu (2011) } \\
\hline & Dry & - & $7.82-8.41$ & $\begin{array}{l}501- \\
1191\end{array}$ & $\begin{array}{l}3.70- \\
9.50\end{array}$ & $\begin{array}{l}5.50- \\
38.70\end{array}$ & - & $\begin{array}{l}21.00- \\
738.99\end{array}$ & - & - & - & \\
\hline $\begin{array}{l}\text { Ogun } \\
\text { State }\end{array}$ & - & - & $6.74-7.59$ & $\begin{array}{l}148- \\
784\end{array}$ & - & - & - & $88-392$ & $26-288$ & $\begin{array}{l}13.39- \\
144.03\end{array}$ & $1.36-4.81$ & Badmus et al.(2015) \\
\hline $\begin{array}{l}\text { Ondo } \\
\text { State }\end{array}$ & GW & $\begin{array}{l}26.50- \\
27.50\end{array}$ & $5.68-6.82$ & - & $\begin{array}{l}0.90- \\
2.40\end{array}$ & $1.60-6.60$ & - & $18-342$ & - & - & $30.0-61.0$ & $\begin{array}{c}\text { Akinbile and Yusoff } \\
\text { (2011). }\end{array}$ \\
\hline $\begin{array}{l}\text { Osun } \\
\text { State }\end{array}$ & GW & $\begin{array}{l}26.30- \\
29.60\end{array}$ & $5.90-7.10$ & $\begin{array}{l}125.00- \\
464.00\end{array}$ & $\begin{array}{l}2.10- \\
5.20\end{array}$ & $2.51-8.60$ & - & - & - & - & $0.05-3.60$ & Adebara et al.(2016) \\
\hline \multirow{2}{*}{$\begin{array}{l}\text { Lagos } \\
\text { State }\end{array}$} & GW & - & $5.01-5.67$ & - & - & - & - & - & - & - & - & \multirow[t]{2}{*}{ Salami et al.(2014) } \\
\hline & SW & - & $6.20-6.24$ & - & - & - & - & - & - & - & - & \\
\hline \multirow[t]{2}{*}{$\begin{array}{l}\text { Kaduna } \\
\text { State }\end{array}$} & $\begin{array}{l}\text { GW } \\
\text { Dry }\end{array}$ & - & $6.21-6.91$ & - & $\begin{array}{l}1.51- \\
1.71\end{array}$ & - & - & $\begin{array}{l}73.40- \\
720.00\end{array}$ & $\begin{array}{c}251.40- \\
646.40\end{array}$ & - & - & \multirow[t]{2}{*}{ Okpanachi, (2012) } \\
\hline & $\begin{array}{l}\text { GW } \\
\text { Wet }\end{array}$ & - & $\begin{array}{c}5.97- \\
6.72 \\
\end{array}$ & - & 1.32 & - & - & $\begin{array}{l}107.40- \\
710.00\end{array}$ & $\begin{array}{c}253.40- \\
655.0 \\
\end{array}$ & - & - & \\
\hline \multirow[t]{2}{*}{$\begin{array}{l}\text { Bayelsa } \\
\text { State }\end{array}$} & $\begin{array}{l}\text { SW } \\
\text { Dry }\end{array}$ & $\begin{array}{l}28.7- \\
30.5\end{array}$ & $7.40-7.57$ & $\begin{array}{l}78.33- \\
89.33\end{array}$ & $\begin{array}{l}1.76- \\
5.68\end{array}$ & $\begin{array}{l}11.67- \\
19.67\end{array}$ & - & $\begin{array}{l}55.00- \\
62.00\end{array}$ & $3.27-5.27$ & $1.98-2.66$ & - & \multirow[t]{2}{*}{$\begin{array}{l}\text { Izonfuo and Bariweni, } \\
(2001)\end{array}$} \\
\hline & $\begin{array}{l}\text { SW } \\
\text { Wet }\end{array}$ & $\begin{array}{l}27.3- \\
29.3 \\
\end{array}$ & 6.9-7.33 & $\begin{array}{c}47.73- \\
54\end{array}$ & $\begin{array}{l}1.38- \\
9.06\end{array}$ & $\begin{array}{l}16.67- \\
28.00\end{array}$ & - & $\begin{array}{l}33.00- \\
37.83 \\
\end{array}$ & $2.27-3.36$ & $2.22-6.27$ & - & \\
\hline $\begin{array}{l}\text { Rivers } \\
\text { State }\end{array}$ & - & - & $6.10-6.80$ & 24.00 & $\begin{array}{l}5.60- \\
11.30\end{array}$ & $\begin{array}{l}0.003- \\
0.04\end{array}$ & $\begin{array}{l}80.00- \\
81.70\end{array}$ & - & $4.00-5.05$ & - & - & Iwuoha et al.(2013) \\
\hline \multirow[t]{2}{*}{ Akwa Ibom } & $\begin{array}{l}\text { GW } \\
\text { Dry }\end{array}$ & $\begin{array}{l}25.80- \\
26.53\end{array}$ & $5.40-5-67$ & $\begin{array}{l}42.33- \\
58.90\end{array}$ & $\begin{array}{l}5.43- \\
5.77\end{array}$ & $0.62-0.77$ & $\begin{array}{l}0.36- \\
0.44\end{array}$ & $\begin{array}{c}49.47- \\
53.30\end{array}$ & - & - & - & \multirow[t]{2}{*}{ Monechot, (2012) } \\
\hline & $\begin{array}{l}\text { GW } \\
\text { Wet }\end{array}$ & $\begin{array}{l}23.70- \\
25.30\end{array}$ & $5.54-6.09$ & $\begin{array}{c}39.97- \\
62.90\end{array}$ & $\begin{array}{l}5.13- \\
6.10 \\
\end{array}$ & $0.45-1.25$ & $\begin{array}{l}0.31- \\
0.45\end{array}$ & $\begin{array}{c}42.85- \\
59.30\end{array}$ & - & - & - & \\
\hline
\end{tabular}

SW: Surface Water, GW: Ground Water. 


\begin{tabular}{|c|c|c|c|c|c|c|c|c|c|c|c|}
\hline State & Source & $\begin{array}{c}\mathrm{Hg} \\
(\mathrm{mg} / \mathrm{l})\end{array}$ & $\begin{array}{c}\mathrm{Pb} \\
(\mathrm{mg} / \mathrm{l})\end{array}$ & $\begin{array}{c}\mathrm{Cr} \\
(\mathrm{mg} / \mathrm{l})\end{array}$ & $\begin{array}{c}\mathrm{Cd} \\
(\mathrm{mg} / \mathrm{l})\end{array}$ & $\begin{array}{c}\mathrm{Cu} \\
(\mathrm{mg} / \mathrm{l})\end{array}$ & $\begin{array}{c}\mathrm{Zn} \\
(\mathrm{mg} / \mathrm{l})\end{array}$ & $\begin{array}{c}M n \\
(\mathrm{mg} / \mathrm{l})\end{array}$ & $\begin{array}{c}\mathrm{Fe} \\
(\mathrm{mg} / \mathrm{l})\end{array}$ & $\begin{array}{c}\text { Co } \\
(\mathrm{mg} / \mathrm{l})\end{array}$ & Reference \\
\hline $\begin{array}{l}\text { NSDWQ } \\
\text { Limits }\end{array}$ & $\mathrm{NA}$ & & 0.01 & 0.05 & 0.05 & 1.00 & 3.00 & 0.20 & $0.5-50$ & & $\begin{array}{c}\text { NSDWQ } \\
(2007)\end{array}$ \\
\hline Cross River & GW & - & $0.005-0.07$ & - & $\begin{array}{l}0.007- \\
0.030\end{array}$ & $0.66-3.01$ & $0.97-4.08$ & - & - & - & $\begin{array}{l}\text { Udofia et } \\
\text { al.(2016) }\end{array}$ \\
\hline Ekiti State & & $0.00-0.01$ & $0.01-0.13$ & - & - & $0.01-0.10$ & $0.19-2.95$ & - & - & $0-0.10$ & $\begin{array}{c}\text { David and } \\
\text { Oluyege, } \\
(2014)\end{array}$ \\
\hline Osun State & GW & - & $<0.001$ & $<0.001$ & $<0.001$ & $<0.001$ & $0-0.041$ & $0-0.57$ & $0-1.36$ & & $\begin{array}{l}\text { Oyelanmi et } \\
\text { al.(2013) }\end{array}$ \\
\hline Ondo State & GW & $0.90-1.40$ & $0.01-1.21$ & $0.001-0.25$ & - & $<0.001$ & $0.30-2.30$ & 0.001 & $0.90-1.40$ & - & $\begin{array}{l}\text { Akinbile and } \\
\text { Yusoff (2011) }\end{array}$ \\
\hline Osun State & GW & - & - & $0.00-0.002$ & - & $0.00-0.005$ & $\begin{array}{l}0.001- \\
0.040\end{array}$ & $0.00-0.006$ & $0.01-0.08$ & - & $\begin{array}{c}\text { Adebara et } \\
\text { al.(2016) }\end{array}$ \\
\hline \multirow[t]{2}{*}{ Lagos State } & GW & - & 0.001 & $\begin{array}{l}0.001- \\
0.010\end{array}$ & 0.001 & $\begin{array}{l}0.009- \\
0.010\end{array}$ & $\begin{array}{l}0.049- \\
0.086\end{array}$ & $\begin{array}{l}0.010- \\
0.016\end{array}$ & $\begin{array}{l}0.098- \\
0.129\end{array}$ & - & \multirow[t]{2}{*}{$\begin{array}{l}\text { Salami et } \\
\text { al.(2014) }\end{array}$} \\
\hline & SW & - & 0.00 & $0.04-0.011$ & 0.00 & $\begin{array}{l}0.014- \\
0.019\end{array}$ & $\begin{array}{l}0.074- \\
0.096\end{array}$ & $\begin{array}{l}0.014- \\
0.019\end{array}$ & $\begin{array}{l}0.089- \\
0.108\end{array}$ & - & \\
\hline \multirow[t]{2}{*}{ Kaduna State } & Dry & - & $0.001-0.096$ & $\begin{array}{l}0.004- \\
0.026\end{array}$ & - & - & $\begin{array}{l}0.006- \\
0.012\end{array}$ & - & $\begin{array}{l}0.100- \\
0.210\end{array}$ & - & \multirow[t]{2}{*}{$\begin{array}{l}\text { Okpanachi, } \\
(2012)\end{array}$} \\
\hline & Wet & - & $0.001-0.036$ & $\begin{array}{l}0.005- \\
0.030\end{array}$ & - & - & $\begin{array}{c}0.0062- \\
0.014\end{array}$ & - & $\begin{array}{l}0.139- \\
0.310\end{array}$ & - & \\
\hline \multirow{2}{*}{$\begin{array}{ll}\text { Akwa } & \text { lbom } \\
\text { State } & \end{array}$} & Dry & - & $<0.001$ & $<0.001$ & $<0.001$ & $<0.001$ & $<0.001$ & $0.11-0.15$ & $0.33-0.36$ & - & \multirow{2}{*}{$\begin{array}{l}\text { Monechot, } \\
\text { (2012) }\end{array}$} \\
\hline & Wet & - & $<0.001$ & $<0.001$ & $<0.001$ & $<0.001$ & $<0.001$ & $0.01-0.04$ & $0.03-0.08$ & - & \\
\hline
\end{tabular}

SW: Surface Water, GW: Ground Water. 
Table 6: Soil Quality Around Some MSW Dumpsite in Nigeria

\begin{tabular}{|c|c|c|c|c|c|c|c|c|c|c|}
\hline State & $\mathrm{pH}$ & $\begin{array}{l}\text { Cond } \\
\mu s / \mathrm{cm}\end{array}$ & $\begin{array}{c}\mathrm{Pb} \\
(\mathrm{mg} / \mathrm{kg})\end{array}$ & $\begin{array}{c}\mathrm{Cr} \\
(\mathrm{mg} / \mathrm{kg})\end{array}$ & $\begin{array}{c}\text { Cd } \\
(\mathrm{mg} / \mathrm{kg})\end{array}$ & $\begin{array}{c}\mathrm{Cu} \\
(\mathrm{mg} / \mathrm{kg})\end{array}$ & $\begin{array}{c}\mathrm{Zn} \\
(\mathrm{mg} / \mathrm{kg})\end{array}$ & $\begin{array}{c}\text { Mn } \\
(\mathrm{mg} / \mathrm{kg})\end{array}$ & $\begin{array}{c}\mathrm{Fe} \\
(\mathrm{mg} / \mathrm{kg})\end{array}$ & Reference \\
\hline $\begin{array}{l}\text { Bayelsa } \\
\text { State }\end{array}$ & 7.60 & - & $14.75-16.14$ & $0.05-0.06$ & $<0.0001$ & - & - & - & - & $\begin{array}{c}\text { Amos-Tautua et } \\
\text { al.(2013) }\end{array}$ \\
\hline Imo State & $\begin{array}{l}4.82- \\
5.10\end{array}$ & $186-200$ & $10.80-12.50$ & - & $0.18-0.21$ & $21.00-33.50$ & $78.20-96.50$ & $18.20-27.14$ & - & $\begin{array}{l}\text { Amadi et } \\
\text { al.(2012) }\end{array}$ \\
\hline Ebonyi State & - & - & $63.40-72.10$ & - & - & $22.50-31.00$ & $62.70-68.50$ & - & $\begin{array}{c}423.00- \\
430.30\end{array}$ & $\begin{array}{c}\text { Anikwe and } \\
\text { Nwobodo, } \\
(2001)\end{array}$ \\
\hline Lagos State & $\begin{array}{l}7.90- \\
8.00 \\
\end{array}$ & - & $<0.001-0.900$ & $12.10-16.20$ & $13.20-13.90$ & $307.3-404.8$ & 110.3-113.7 & - & - & $\begin{array}{l}\text { Oluseyi et } \\
\text { al.(2014) }\end{array}$ \\
\hline Bauchi State & - & - & $4.31-10.63$ & $5.04-8.31$ & $0.21-1.21$ & $0.79-2.07$ & - & - & - & $\begin{array}{l}\text { Buteh et } \\
\text { al.(2013) }\end{array}$ \\
\hline Ondo State & - & - & $24.7-59.70$ & - & - & $31.7-101.9$ & - & - & - & Akinbile, (2012) \\
\hline Ebonyi State & - & - & $12.80-14.35$ & - & $0.65-0.80$ & $3.60-4.30$ & - & - & - & $\begin{array}{l}\text { Njoku et } \\
\text { al.(2014) }\end{array}$ \\
\hline Lagos State & $\begin{array}{l}5.65- \\
5.69\end{array}$ & - & $0.019-0.029$ & $0.269-0.0279$ & 0.000 & $2.70-3.01$ & $\begin{array}{l}11.980- \\
12.460\end{array}$ & $5.981-6.700$ & $\begin{array}{l}37.475- \\
39.650\end{array}$ & $\begin{array}{l}\text { Salami et } \\
\text { al.(2014) }\end{array}$ \\
\hline
\end{tabular}


Table 7: Microbial Diversity of some MSW Dumpsites in Nigerian

\begin{tabular}{|c|c|c|c|c|c|}
\hline Species & \begin{tabular}{|l|}
$\begin{array}{l}\text { Odeyemi, } \\
(2012)\end{array}$ \\
\end{tabular} & \begin{tabular}{|lll}
$\begin{array}{l}\text { Ambrose et al. } \\
(2015)\end{array}$ & & \\
\end{tabular} & $\begin{array}{l}\begin{array}{l}\text { Oluseyi et al. } \\
(2014)\end{array} \\
\end{array}$ & $\begin{array}{c}\text { Ogunmodede et al. } \\
(2014)\end{array}$ & Nagadu, (2010) \\
\hline \multicolumn{6}{|c|}{ BACTERIA SPECIES } \\
\hline Escherichia coli & - & + & + & - & + \\
\hline Bacillus spp. & - & + & + & - & - \\
\hline Staphylococcus spp. & + & + & + & - & + \\
\hline Salmonella spp. & + & - & - & & + \\
\hline Micrococcus spp. & - & + & - & - & - \\
\hline Enterococcus spp. & + & - & - & - & - \\
\hline Pseudomonas spp. & + & - & - & - & - \\
\hline Klebsiella spp. & + & - & - & - & + \\
\hline Shigella spp. & - & - & - & - & + \\
\hline Lactobacillus spp. & - & - & - & + & - \\
\hline Serratia spp. & + & - & - & - & - \\
\hline Proteus Spp. & - & - & - & - & + \\
\hline \multicolumn{6}{|c|}{ FUNGI SPECIES } \\
\hline Aspergillu spp. & - & + & + & + & + \\
\hline Penicillium spp. & - & + & + & + & - \\
\hline Fusarium spp. & - & + & + & + & - \\
\hline Rhizopus spp. & - & + & - & + & - \\
\hline Trichoclerma spp. & - & - & + & + & - \\
\hline Absidia spp. & + & + & - & + & - \\
\hline Mucor spp. & - & + & - & + & - \\
\hline Candida spp. & - & + & - & - & - \\
\hline Neurospora spp. & - & - & - & + & - \\
\hline Alternaria spp. & - & + & - & & - \\
\hline Cephalosporium spp. & - & - & - & + & - \\
\hline Saccharomyces spp. & - & - & - & + & - \\
\hline Cladosporium spp. & - & + & - & & - \\
\hline Helminthosporium & - & - & - & + & - \\
\hline Pullularia spp. & - & - & - & + & - \\
\hline Triamnidium spp. & - & - & - & + & - \\
\hline Phoma spp. & - & + & - & - & - \\
\hline Geotrichum spp. & - & + & - & - & - \\
\hline Zygorrhynchus spp. & - & - & - & + & - \\
\hline
\end{tabular}

Keys: + means endemic species, - means Non-endemic or not investigated species. 
As presented in Table 7, the following predominant bacteria species were reported in some MSW dumpsites in Nigeria including; Escherichia coli, Staphylococcus spp, Klebsiella spp, Salmonella spp, Bacillus spp, Shigella spp, Proteus Spp, Pseudomonas spp, Salmonella spp, Lactobacillus spp, Micrococcus spp., Serratia spp, Enterococcus spp. Which fungi species associated with dumpsites are; Aspergillu spp, Alternaria spp. Fusarium spp, Rhizopus spp, Candida spp., Penicillium spp, Trichoderma spp, Triamnidium spp., Neurospora spp, Mucor spp, Phoma spp., Neurospora spp., Geotrichum spp., Cladosporium spp., Cephalosporium spp. etc. (Nagadu, 2010; Odeyemi, 2012; Oluseyi et al.2014; Ogunmodede et al.2014; Igborgbor, and Ogu, 2015; Ambrose et al. 2015).

\subsection{The Nigerian Challenges and Prospects in Solid Waste Management}

As opposed to developed nation where total recovery and recycling of waste has become a practice; the challenges associated with municipal waste management is Nigerian has become a source of concern. Although, these cases are unlimited to Nigerian urban cities as it varies geopolitically depending on sensitization of the populace (Momodu et al.2011), legislation, as well as the degree of Government policies and commitment for effective waste management. It was also suggested that these challenges are compounding but could be related to economic, technological, psychological and political factors (Abila and Kantola, 2013). One major challenge of the populace is their inability to segregate or characterized waste prior to their disposal. In the same vein when waste is piled up in dumpsites the practice of insitu burning becomes a rude and inappropriate option, insitu burning causes atmospheric pollution as the ambient air quality is impacted upon. Majority of the populace either lack or have unsafe temporary waste sanitary bin. Unsafe household waste sanitary bin obliges a good fathom for common household vectors that transmit major diseases of public health, including rats and cockroaches. Some wastes are usually not properly packaged in airtight containment and after transformation they produce foul odour.

As suggested by Suh (2001), profound analysis and subsequent comprehensive synthesis are good recipes for product delivery and service design. As such in order to ameliorate the problems associated with poor waste management, there is absolute need to apply the right approach. Abila and Kantola (2013), criticize the fruitless and resource consuming push-style design and suggested two basic approaches, which are focused on product design and knowledge-management solutions. For effective and sustainable management of MSW there is the need to involve all stakeholder in order to place value the adverse effects of poor waste management and effective legislation to will prohibit precarious dumping of waste as well as effective recycling aimed at economic impact such as the waste to wealth policies which aims at reducing, re-using and recycling waste. Also, as suggested by Ogwueleka, (2009), there is the need for Government to collaborate with research and development institutions.

\section{CONCLUSION}

This review on the environmental impacts of MSW in Nigeria revealed that, Government and all stakeholders need to show more commitment for the effective and safe management of waste stream. Unfortunately, some data emerging show values which exceed the standard regulatory limit for both air and water quality. Due to poor and inappropriate management of waste streams are often subjected to biological and physicochemical transformation, that can produce toxic leachate and foul odour that infringes on ambient air quality. Leachate from dumpsite can also contaminate the soil, which further infiltrates to contaminate ground water or transported by runoff which can be bioaccumulated by aquatic biota and other forms of biodiversity. Due to the significant impacts posed by MSWs; Government on one hand should provide recycling and treatment facilities for effective management MSWs, and effective legislation on the other hand in order to deter precarious dumping. Sensolato, the populace should be sensitized on safe and eco-beneficial management of waste including recycling, waste to wealth policy etc.

\section{REFERENCES}

Abur, B. T., Oguche, E. E., Duvuna, G. A. (2014). Characterization of Municipal Solid Waste in the Federal Capital Abuja, Nigeria. Global Journal of Science Frontier Research: Environment \& Earth Science, 14(2): 1 6.

Adamu, I. M., Dibal, H. I., Duhu, B. Y. (2014). Disposal and Management of Solid Waste in Damaturu, Yobe State, Nigeria: Challenges and Implications. Journal of Environmental Issues and Agriculture in Developing Countries, 6(2): 54 - 63.

Adebara, S. A, Afolayan, A., Omajali D. I, Olatuni, A. A. (2016). "Assessment of The Effects of Solid Waste Dumpsite on Groundwater in Osogbo And Ede Metropolis Osun State, Nigeria" International Journal of Engineering Technologies and Management Research, 3(2):1-21. 
Adedibu, A. A (1985). "Comparative analysis of solid waste composition and generating in two cities of developing nation." The Environmentalist, 5(2): 123 - 127.

Adejobi, O. S., Olorunnimbe, R. O. (2012). Challenges of Waste Management and Climate Change in Nigeria: Lagos State Metropolis Experience. African J. Sci. Res. 7(1): 346 - 362.

Adekunle, I. M., Adebola, A. A., Aderonke, K. A., Pius, O. A., Toyin, A. A. (2011). Recycling of organic wastes through composting for land applications: A Nigerian experience. Waste Management Res., 29(6): 582 - 93.

Aderinola O. J., Clarke E. O., Olarinmoye O. M., Kusemiju V. and Anatekhai M. A. (2009). Heavy Metals in Surface Water, Sediments, Fish and Perwinkles of Lagos, Lagoon. American-Eurasian J. Agric. \& Environ. Sci., 5(5): 609-617.

Agwu, A. and Ozeh, R.N. (2013). Evolution of Ambient Air. Quality of Aba Metropolis, Nigeria. International Journal of Current Research, 5(4):843 - 844.

Ahmed, Y. A. (2012). Potential Impacts of Climate Change on Waste Management in Ilorin City Nigeria. Global Journal of Human Social Science, 12(6): 39 - 48.

Akinbile, C. O (2012). Environmental Impact of Landfill on Groundwater Quality and Agricultural Soils in Nigeria. Soil and Water Resource, 7(1): 18 - 26.

Akinbile, C. O., Yusoff, M.S., (2011). Environmental Impact of Leachate Pollution on Groundwater Supplies in Akure, Nigeria. International Journal of Environmental Science and Development, 2(1): 81-86.

Akinjare, O. A. (2011). Impact of Sanitary Landfills on Urban Residential Property Value in Lagos State, Nigeria. Journal of Sustainable Development, 4(2): 48 - 60.

Amadi, A. N., Olasehinde P. I., Okosun E. A., Okoye N. O., Okunlola I. A., Alkali, Y. B., Dan-Hassan M. A. (2012). A Comparative Study on the Impact of Avu and Ihie Dumpsites on Soil Quality in Southeastern Nigeria. American Journal of Chemistry, 2(1): 17 - 23.

Ambrose, I., Braid, W., Essien, J. P (2015). Assessment of Air Quality (Bioaerosols) of the Municipal Waste Dumpsite in Uyo Urban, Akwa Ibom State, Nigeria. International Journal of Scientific and Research Publications, 5(9): 1 - 6.

Amuda, O. S., Adebisi, S. A., Jimoda, L. A., Alade, A.O (2014). Challenges and Possible Panacea to the Municipal Solid Wastes Management in Nigeria. Journal of Sustainable Development Studies, 6(1): 64 -70.

Angaye, T.C.N., Zige, D.V. and Izah, S.C. (2015). Microbial load and heavy metals properties of leachates from solid wastes dumpsites in the Niger Delta, Nigeria. Journal of Environmental Treatment Techniques, 3(3): $175-180$.

Angaye, T.C.N., Angaye W.T., Oyinke G.N., Konmeze O. (2016). Environmental Impact of Scrap Metal Dumpsites on Vegetation, Soil and Groundwater in Yenagoa Metropolis, Nigeria. Journal of Environmental Treatment Techniques. 4(3): 31 - 36.

Anikwe, M.A.N., Nwobodo, K.C.A. (2001). Long term effect of municipal waste disposal on soil properties and productivity of sites used for urban agriculture in Abakaliki, Nigeria. Bioresource Technology 83(2002): 241 250.

Anyakoha, E. U., Egboeli, C. C. (1993). Household Solid Waste Disposal Practice of Women in two Nigerian urban towns; implication for Environmental Education, Unpublished Research Report, funded by Nigerian Environmental Study/Action Team (NEST).

Ayuba, K. A., Abd-Manaf, L., Sabrina A. H., Azmin, S. W. (2013). Current Status of Municipal Solid Waste Management Practise in FCT Abuja. Research Journal of Environmental and Earth Sciences, 5(6): 295 304.

Babayemi, J. O., Dauda, K. T. (2009). Evaluation of solid waste generation, categories and disposal options in developing countries: A case study of Nigeria. J. Appl. Sci. Environ. Manage., 13(3): 83 - 88.

Badmus, B. S., Ozebo, V. C., Idowu, O. A., Ganiyu, S. A., Olurin, O. T. (2014). Physico-chemical Properties of Soil Samples and Dumpsite Environmental Impact on Groundwater Quality in South Western Nigeria. The African Review of Physics, 9(0015): $103-114$.

Bahnasawy, M., Khidr A., \& Dheina, N. (2011). Assessment of heavy metal concentrations in water, plankton, and fish of Lake Manzala, Egypt. Turk. J. Zool., 35(2), 271-280.

Barakat, C., Zhang, S., Siddiqua, A., Dghaim, R. (2015). Air Quality and Respiratory Health among Adolescents from the United Arab Emirates. Journal of Environmental and Public Health. 2015: 1-15.

Barman, S. C., Kumar, N., Singh, R., Kisku, G. C., Khan, A. H., Kidwai, M. M., \& Murthy, R. C. (2010). Assessment of urban air pollution and it's probable health impact, Journal of Environmental Biology, 31: 913-920.

Botkin, D. B., Keller (1997). Environmental Science: Earth as a Living Planet, 2nd Edition.

Burney, S., Phillips, R., Coleman, T., Rampling, T. (2011). Energy implications of the thermal recovery of biodegradable municipal waste materials in the United Kingdom. Journal of Waste Management, 31: 1949 1959.

Buteh, D. S., Chindo, I. Y. Ekanem, E. O., Williams, E. M. (2013). "Impact Assessment of Contamination Pattern of Solid Waste Dumpsites Soil: A Comparative Study of Bauchi Metropolis." World Journal of Analytical Chemistry 1(4): 59 - 62. 
David, O. M., Oluyege, A. O. (2014). Effect of Open Refuse Dumpsite on the Quality of Underground Water Used for Domestic Purposes in Ado-Ekiti, Nigeria - A Public Health Awareness Study. Journal of Environment and Ecology. 5(2): 1 - 9.

Doan, P. L. (1998). Institutionalizing household waste collection: the urban environmental management project in Cote d'Ivoire. Habitat International, 22(1):27 - 39.

Ene A., Boşneagă A. and Georgescu L. (2009). Determination of Heavy Metals in Soils using XRF Technique, University of Galati, Faculty of Sciences, Chemistry Department, 111 Domneasca St, 800201 Galati, Romania pp. 815-820.

Ezekwe, C. I., Agbakoba, C., Igbagara, P. W. (2016). Source Gas Emission and Ambient Air quality around the Eneka co-disposal landfill in Port-harcourt, Nigeria. International Journal of Applied Chemistry and Industrial Sciences, 2(1): $11-23$.

Eshalomi-Mario, T.N and. Tanee, F. B. G (2015). Phytodiversity Assessment in Abandoned Solid Waste Dumpsites in Port Harcourt, Nigeria. Annual Research \& Review in Biology, 6(6): $379-389$.

Falusi, B. A., Odedokun, O. A., Abubakar, A., Agoh, A. (2016). Effects of dumpsites air pollution on the ascorbic acid and chlorophyll contents of medicinal plants, Cogent Environmental Science, 2: 1- 13.

FEPA, (1991). "Guidelines and Standards for Environmental Pollution Control in Nigeria," Federal Environmental Go- vernment Protection Agency.

Hossain, M. L, Das, S. R., Talukder, S., Hossain, M. K. (2014). Generation of Municipal Solid Waste in Commercial City of Bangladesh. Journal of Environmental Treatment Techniques, 2(3): 109-114.

Igbinomwanhia, D. I (2012). Characterization of Commercial Solid Waste in Benin Metropolis, Nigeria. Journal of Emerging Trends in Engineering and Applied Sciences, 3(5):834 - 838.

Igborgbor, J.C., Ogu, I.G. (2015). Microbial Assessment of Air in The Vicinity of Some Dump Sites in Delta State. International organization of Scientific Research, 5(1): 7-15.

Iwuoha, G. N., Osuji, C., Onwuachu, I. U. (2013). Impact of waste dump on the sediment and surface water quality of Otamiri River, Nigeria. J. Appl. Sci. Environ., 17(4): 573 - 575.

Izah, S. C., Angaye, T. C. N. (2016). Heavy metal concentration in fishes from surface water in Nigeria: Potential sources of pollutants and mitigation measures. Sky Journal of Biochemistry Research, 5(4): 31-47.

Izonfuo, W. A. L., Bariweni, A. P. (2001). The Effect of Urban Runoff Water and Human Activities on Some Physico-chemical Parameters of The Epie Creek in The Niger Delta. J. Appl. Sci. Environ. Mgt., 5(1): 47 - 55.

Jalil, A., (2010). Sustainable development in Malaysia: A case study on household waste management. Sustainable Development, 3(3): 91 - 102.

Kola-Olusanya, A. (2012). Impact of Municipal Solid Wastes on Underground Water Sources in Nigeria. European Scientific Journal, 8(11): 1- 19.

Lam, M. K., Lee, K. T. (2011). Renewable and sustainable bioenergies production from palm oil mill effluent (POME): Win-win strategies toward better environmental protection. Biotechnology Advances, 29: 124 - 141.

Momodu, N. S., Dimuna, K. O., Dimuna J. E. (2011). Mitigating the Impact of Solid Wastes in Urban Centres in Nigeria. J Hum Ecol, 34(2): 125 - 133.

Monechot, W. O. (2012). Leachate, Groundwater, Surface Stream, Treated Water and Soil Sharacteristics of the vicinity of a Municipal Solid Waste Dumpsite at Uyo Metropolis, Akwa - Ibom State, Nigeria. M.Sc Thesis Submitted to Nigerian University Nsukka, Enugu State, Nigeria.

Mor, S., Ravindra, K., Dahiya, R. P., Chandra, A. (2006). Leachate Characterization and assessment of groundwater pollution near municipal solid waste landfill site. Environ. Monit. Assess. 4: 325 - 334.

Musa, A. A., Labo, A. S., Lamido, S. M., Salisu, S. A., Ibrahim, M. B., Bello, N. (2016). Characterization of Municipal Solid Waste, In Kazaure Local Government Area, Jigawa State, Nigeria. International journal of engineering sciences \& research Technology, 5(7): 292 - 296.

Nabegu, A. B. (2010). An Analysis of Municipal Solid Waste in Kano Metropolis, Nigeria. J Hum Ecol., 31(2): 111119.

Nabegu, A. B. (2014). The Potential of Municipal Solid Waste as a Clean Development Mechanism (CDM) Project in Kano Metropolis, Nigeria. Greener Journal of Social Science 4 (2): 130 - 138.

National Population Commission-NPC (2005). Report of 2003 Demography and Health National Demography and Health Survey (NDHS) National Population Commission Abuja Nigeria.

Nautiyal Jyoti., Garg M.L., Sharma Manoj Kumar, Khan Asif Ali, Thakur Jarnail S. and Kumar Rajesh (2007): Air Pollution and Cardiovascular Health in Mandi-Gobindgarh, Punjab,India - A Pilot Study. Int. J. Environ. Res. Public Health. 4(4), 268-282.

Nayono S. E. (2010). Anaerobic digestion of organic wastes for energy. Scientific Publishing. 7 - 20.

Nigerian Environmental Study/Action Team (1991). Nigerian's Threatened Environment. A National profile, NEST, Ibadan, Nigeria.

NSDQW (Nigerian Standard for Drinking Water Quality) (2007). Nigerian Industrial Standard NIS 554, Standard Organization of Nigeria. Pp. 15-17.

Njoku, C. (2014). Effect of Waste Dumpsites on Water and Air Qualities in Abakaliki, Southestern Nigeria. International Journal of Plant \& Soil Science, 4(5): 455 - 460. 
Nwakanma, C., Ikwa U. E., Ubuoh, E. I (2016) Assessment of Ambient Air Quality with Special Reference to $\mathrm{NO}_{2}$ in the Waste Dump Site at Osisoma Ngwa LGA, Nigeria. J Ecosys Ecograph 6(3):197-199.

Obodai E.A., Boamponsem L.K., Adokoh C.K., Essumang D.K., Villawoe B.O., Aheto D.W. and Debrah J.S. (2011). Concentration of Heavy Metals in two Ghanaian Lagoons. Archive of Applied Science research, 3(3): 177-187.

Odeyemi, A. T (2012). Antibiogram Status of Bacterial Isolates from Air Around Dumpsite of Ekiti State Destitute Centre at llokun, Ado-Ekiti, Nigeria. Journal of Microbiology Research, 2(2): 12 - 18.

Ogedengbe, C., \& Akinbile, C. O. (2007). Well waters disinfection by solar radiation in Ibadan, Nigeria. Nig. J. Technolog. Develop., 5(1): 39 - 47.

Ogunmodede, O. T., Adewole, E., Ajayi, O. O, Onifade, A. K. (2014). Environmental Assessment of Solid Waste Management in Nigeria: A case study of Ikere Ekiti, Ekiti State. Journal of Physical and Chemical Sciences, $1(1): 1-8$.

Ogwueleka, T. C., 2009. Municipal solid waste characteristics and management in Nigeria. Iran J. Environ. Health Sci. Eng., 6(3): 173-180.

Ohimain, E. I., Izah, S. C (2017). A review of biogas production from palm oil mill effluents using different configurations of bioreactors. Renewable \& Sustainable Energy Reviews. 70: 242-253.

Ohimain, E. I., Izah, S. C. (2014a). Potential of Biogas Production from Palm Oil Mills' Effluent in Nigeria. Sky Journal of Soil Sciences and Environmental Management, 3(5): 50 - 58.

Ohimain, E. I., Izah, S. C. (2014b). Possible contributions of palm oil mill effluents to greenhouse gas emissions in Nigeria. British Journal of Applied Science and Technology, 4(33): 4705 - 4720.

Okeke, P. N. (2014). Impact of Solid Waste on Physico-Chemical Properties of Ferrealsol in Owerri, Nigeria. African Research Review, 8(3): 116 - 122.

Okey, E. N., Umana, E. J., Markson, A. A., Okey, P. A. (2013). Municipal Solid Waste Characterization and Management in Uyo, Akwa Ibom State, Nigeria. Transactions on Ecology and The Environment, 173(6): 639 - 648.

Okpanachi, A. S. (2012). Effects of Solid Waste Dumpsites on Groundwater Quality in Samaru, Zaria Kaduna State, Nigeria. M.Sc Thesis Submitted to Ahmadu Bello University, Zaria, Kaduna State, Nigeria.

Oluseyi, T., Adetunde, A., Amadi, E. (2014). Impact Assessment of Dumpsites on Quality of Near-By Soil and Underground Water: A Case Study of An Abandoned and A Functional Dumpsite in Lagos, Nigeria. International Journal of Science, Environment and Technology, 3(3): 1004 - 1015.

Omran A., Gavrilescu M. (2008). Municipal solid wastes management in developing countries: Perspective on Vietnam, Environmental Engineering and Management Journal, 7(4): 469-478.

Onibokan, A. G. (2000). Affordable Technologies and Strategies for Waste Management in Africa; Lessons from Experience, Centre for advance Social Science, CSSAD Monograph, Series No. 13.

Onwughara, I. N., Nnorom, I. C., Kanno, O. C. (2010). Issues of roadside disposal habit of municipal solid waste, environmental impacts and implementation of sound management practices in the developing country Nigeria. International Journal of Environmental Science and Development, 1(5): 409 - 418.

Oyekan, T. K., Sulyman, A.O. (2013). Health Impact Assessment of Community-based Solid Waste Management Facilities in Ilorin West Local Government Area Kwara State, Nigeria. Journal of Geography and Regional Planning, 8(6): $26-36$.

Oyelami, A. C., Aladejana, J. A., Agbede O. O. (2013). Assessment of the impact of open waste dumpsites on groundwater quality: a case study of the Onibu-Eja dumpsite, southwestern Nigeria. Procedia Earth and Planetary Science 7: $648-651$.

Rajaganapathy V., Xavier F., Sreekumar D. and Mandal P. K. (2011). Heavy Metal Contamination in Soil,Water and Fodder and their presence in Livestock and Products: A Review. Journal of Environmental Science and Technology,4:234-249.

Rim-Rukeh, A. (2014) An Assessment of the Contribution of Municipal Solid Waste Dump Sites Fire to Atmospheric Pollution. Open Journal of Air Pollution, 3, 53-60.

Sadiu, M. (2011). Effect of refuse dumps on ground water quality. Advances in Applied Science Research, 2(6):595-599

Schwarz-Herion, O., Omran, A., Rapp, H. P. (2008). A Case Study on Successful Municipal Solid Waste Management in Industrialized Countries by the example of Karlsruhe City, Germany. Journal of Eng. Annals, 6(3): 266 - 273.

Sharholy, M., Ahmad, K., Mahmood, G., Trivedi, R.C. (2008). Municipal solid waste management in Indian cities - a review. Waste Management 28(2), 459-467.

Shayley H., McBride M, and Harrison E. (2009). Sources and Impacts of Contaminants in Soils. Cornell Waste Management Institute.pp.1-6.

Singh SK 1998. Solid waste management: An overview of environmental pollution. Environmental Control Journal, 1(3): 50 - 56.

Stavrianou W. (2007). The Western Australian Contaminated Sites Act 2003: The Applicability of Risk Assessment as a basis for the Assessment and Management of Site Contamination, www.awu.edu.au pp. 192. 
Suh N.P. (2001). Axiomatic design: Advances and Applications. Oxford University Press, USA.

Uba, S. (2015). Environmental Impact Assessment of Dumpsites in Zaria Metropolis, Kaduna State, Nigeria. M.Sc Thesis, Ahmadu bello University, Zaria Nigeria.

Ubouh, E.A., Nwawuike, N., Ikwa, L (2016). Evaluation of the on-site and off-site ambient air quality (aaq) at Nekede waste dumpsite, Imo state, Nigeria. British Journal of Earth Sciences Research, 4(1): $18-22$.

Udofia, U. U., Udiba, U. U., Udofia., L. E., Ezike N. N., Udiba S. U. (2016). Assessment of the Impact of Solid Waste Dumps on Ground Water Quality, Calabar Municipality, Nigeria. Journal of Advance Research in Biology \& Pharmacy Research. 1(4): 18 - 34.

Ugwuishiwu B. O., Nwodo J. C., Echiegu E. A. (2016). Municipal Solid Waste Characterization in Nsukka Urban in South East Nigeria. Transylvanian Review, 24(7): 808 - 815.

van Beukering P., Sehker M., ReyerGerlagh R., Kumar V., (1999). Analysing urban solid waste in developing cuntries: a pespective on Bangalore, India, Working Paper No 24, Collaborative Research in the Economics of Environment and Development (CREED), Institute for Social and Economic Change (ISEC), Nagarbhavi, Bangalore, India.

Weli, V.E., Adekunle, O. (2014). Air Quality in the Vicinity of a Landfill Site in Rumuolumeni, Port Harcourt, Nigeria. Journal of Environment and Earth Science, 4(10): 1 - 9.

WHO (World Health Organization) (2003). Lead in drinking-water. Background document for preparation of WHO Guidelines for drinking-water quality. Geneva, World Health Organization.

Worksafe V. (2005). Industry Standard Contaminated Construction Sites. EPA Victoria, www.worksafe.vic.gov.au, First Edition. pp. 1-28.

World Health Organization, 7 Million Premature Deaths Annually Linked to Air Pollution, World Health Organization, Geneva, Switzerland, 2014, http://www.who.int/mediacentre/news/releases/2014/airpollution/en/.

Cite this Article: Angaye TCN and Abowei JFN (2017). Review on the Environmental Impacts of Municipal Solid Waste in Nigeria: Challenges and Prospects. Greener Journal of Environmental Management and Public Safety, 6(2): 018-033, http://doi.org/10.15580/GJEMPS.2017.2.062117079 